\title{
Poland: A Dark Side of Church Cultural Policy
}

\author{
Konrad Szocik \\ University of Information Technology and Management in Rzeszow, \\ Poland
}

e-mail: kszocik@wsiz.rzeszow.pl

Aneta Szyja

Adam Mickiewicz University, The Department of Dutch and South African Studies, Poznań, Poland

e-mail:as21163@st.amu.edu.pl

\begin{abstract}
:
The cultural policy of the Roman Catholic Church in Poland is incorporated into state-run cultural policies. The organs of public authority enforce the objectives of Church regardless of Church's actual ability to influence the society. It should be pointed out that the secularization of religion in Poland is frequently misinterpreted and usually equated with its deprivatization. It is worth mentioning that Catholicism is the dominant religion of the country and the Roman Catholic Church has hold a special position in Poland and play a major role in the country's social and political life. In practice, however, Polish society appears to be religiously indifferent. This paper proves that the official, state-run cultural policy in Poland is based on favoritism of the Roman Catholic Church, regardless of Church's actual ability to wield influence on society. Thus, there is a variety of implicit and explicit cultural policies implemented by the authorities to support Church. This work also aims at addressing the question of social attitudes to women, especially the one concerning the UN and EU law embracing women's rights, until recently still not implemented in Poland. This paper further explores some peculiarities of this topic as an example of a specific outcome of Church cultural policy and its impact on both the past and present-day society.

Keywords: The Church, Cultural Policy, Women, Gender, Democracy.
\end{abstract}

\section{Introduction}

The issues of secularization, post-secularization, privatization and deprivatization of religion and numerous implications on social, cultural, political or philosophical contexts have been widely discussed [19], [7], [5]. These analyses delineate the Western European cultures but do not allude to the Polish reality. We would like to touch upon certain elements that are peculiar to the contemporary Polish cultural policy concerning the special position of the Roman Catholic Church which, however, do not reflect its actual power to wield influence upon society. In a sense, the explicit cultural policy of Church, which has functioned as an authoritarian institution, is strongly advocated by the state authorities which oftentimes implicitly (occasionally also explicitly) function as an executor of Church cultural policy. What we mean here, is the term of implicit cultural policy 
expounded by Jeremy Ahearne and extended by Oliver Bennett [5, p. 157]. It is, therefore, understood that Church, as an agent of cultural policy, aims at shaping and controlling consciousness of believers and is of paramount importance, especially in Poland [5, pp. 167-168]. Nevertheless, the Polish case remains difficult to categorize. The special emphasis should be put on the situation of Polish women [20], [13, pp. 431-435], [15]. There is a particularly strong opposition in Poland against the UN and EU laws protecting women, which stems from the present-day Church cultural policy and the outcomes of its social and mental influence in the past.

One of the most important reasons of the present-day increased cultural policy of Church in Poland is the absence of commonly shared ideas upon which the nation could base their national identity and through which this identity could be expressed. This lack of the commonly shared elements of identity and the absence of an idea of "cultural citizenship", which is fundamental when it comes to cultural policy [17, p. 34], may be one of the main reasons why Church in Poland inclines to impact the society both implicitly and explicitly, unlike other countries in the Western Europe. On the one hand, Polish national identity and cultural continuity had been disturbed due to numerous political changes that occurred in the past and which significantly influenced the society's perception of national identity. Therefore, the Polish are remarkably less inclined to identify themselves with the state, which in turn, explains the logic behind the perception of Church as an important part of Polish society. In fact, Church had been perceived as a sort of substitute of the state over the years. On the other hand, even such a significant event as the Fall of the Berlin Wall, which goes back to 1989, did not give rise to any new cultural and ideological rudiments which could serve as the foundation of national identity.

Nowadays, there is a range of mindsets which appears to be somewhat superficial and to which the majority of Polish society seems to be indifferent. However, at the very top of it, there is one distinctive lineament, that is: the Roman Catholic Church. The nature of this institution could be described as political authoritarianism. In Poland, the Church attempts to maintain its dominant position not only in the area of culture but, first and foremost, in politics, successfully perpetuating its influence especially through the medium of cultural policy. Church is aware of a significant role it played in a communist Poland. Some events during the communist period in Poland, such as: the Battle for a Church and the Nowa Huta Cross in Cracow or the sermons of Jerzy Popiełuszko, a Roman Catholic priest associated with the Solidarity union, murdered by the agents of the Polish communist Security Service of the Ministry of Internal Affairs can illustrate this point. What Church in Poland wishes to achieve is creating the Polish history and national identity on the basis of Church's strong historical function. Still, Church is treated by the majority of Polish society only instrumentally (as it is a case for some other institutions in Poland).

After the Fall of the Berlin Wall the Church in Poland tries to manipulate both the political authorities as well as society by sexual matters. One of the first topics was the case of couples without marriage. In recent 2-3 years the main topic was the question of "gender ideology" and „Convention on preventing and combating violence against women and domestic violence". We consider this case in our paper. Currently, we can observe another topic associated with the sexual matters: the case of "in vitro". The Church lost the ideological battle against convention because this document probably will be soon ratified despite the great opposition of the Church. This is why the Church immediately focuses on a new "gender" question, "in vitro". The better example for consideration is the case of the convention. This complete history shows what mechanisms and strategies the Church in Poland uses to hold its position. First of all, we can see how the question of woman is understood in the current Poland and how, in specific way, in the polish society are connected the following questions: European idea of equality and justice, idea of citizen society (implemented especially by European Union since 2004) and democratic approach on the one side, and religious tradition and historically strong position of the Church, superficial religiosity and practical atheism on the other hand. Consequently, we observe a chaos of ideas and a lack of dominant and meaningful social and cultural beliefs and ideas. Probably, this ideological "chaos" causes that the Church cultural policy which is against civil laws preventing women, is not only possible but is still so strong and influential. In our paper we are focus on an analysis of these 
mentioned above questions from the phenomenological point of view and critical analysis. However, deep sociological surveys and research could be found in many works of Józef Baniak who underlined some negative social and moral results of inappropriate cultural policy of Church [2], [3].

\section{The Church Implicit and Explicit Cultural Policy}

When taking into consideration a global context, it can be noticed that the "strategic canonization", promoted especially by Pope John Paul II, was used by Church as one of the main tools of its cultural policy to shape the secular world [6]. This practice of creating saints on a massive scale, which can be viewed as the production of Church's "international celebrity saints" some of them being: Padre Pio and Mother Theresa, connotes the implicit cultural policy [6, pp. 441, 451]. When analyzing the Polish case there is a particular link between implicit and explicit cultural policy. This phenomenon was uncovered by Jan Woleński, a Polish logician and philosopher. He prepared an appeal to Polish organs of authority, published in Gazeta wyborcza 17 October 2014, in which he underlines the fact that the organs of authority do not respect the principle of neutrality incorporated in the constitution of 1997 [27]. This appeal was signed by fifteen Polish professors (6 psychologists, 4 lawyers, 2 philosophers, a Polish scholar, a historian and a sociologist). It has been signed online by another 24341 people (as for 29 November 2014). Woleński's main thesis is of a key significance in view of a current cultural policy guided by the state and Church. He is primarily concerned with the impact of Church on the following aspects of politics: educational issues (religious education in public schools), financial issues (public financial support provided to Church) and ethical issues (domestic violence, nature of relationships). He states that it is quite natural for Church to pursue its particular aims. However, it is not usual for the secular state authorities to accept these demands and implement them against the constitution [27]. Also from the perspective appropriate for the biological evolution, this Church approach is natural, because every organization, human as well as animal populations want to take an advantage over other [23].

One of the most important issues is religious education in public schools. This is not a compulsory subject and pupils attend the classes of their own volition. Parents determine whether their children should attend religion classes or ethics classes or none of them. The classes, nevertheless, are scheduled only in the middle of a timetable on request of Church as it do not acquiesce to arrange it at the end of a timetable (risk of low attendance rate). A special kind of declaration requested by Ministry of Education has to be fill out by parents who do not wish their children to attend religious education. This request of Ministry of Education is, however, inconsistent with the Polish constitution. This is yet another example of how the Ministry consistently implements the suggestions made by the Church [28]. According to Woleński, the Church invades the public sphere by forcing religious worldviews into public debates and is strongly involved in political activity. Consequently, other important social and economic issues are marginalized. In some cases, the immense power of Church reverberates throughout the decisions made by the organs of authority in the area of social matters and oftentimes result in serious repercussions as it may be seen in case of domestic violence. Council of Europe Convention on preventing and combating violence against women and domestic violence (Istanbul, 11 May 2011) underlines that its main purpose is to "protect women against all forms of violence" and "the elimination of all forms of discrimination against women" [10]. It may be seem incredible for the Western societies that this convention has still not been ratified in Poland. It was rejected by two ruling parties and the largest opposition party on 21 October 2014 [13]. Every year, in Poland some 700000 to 1000000 women become victims of some forms of violence (30000 of which are rape victims). Each year, in Poland 150 women are killed as the result of domestic violence [1]. The main enemy of this European Convention is Church who claims that this regulation destroys a Catholic family. The homily given by Polish Bishop Kazimierz Ryczan on $20^{\text {th }}$ September 2014 in Częstochowa casts light on this matter: 
Dear Members of Parliament! Polish law is in your hands. (...) Europe has no right to interfere in our families! Dear Mr President! You have a decisive voice. Your signature can solve this problem [22].

It can serve as an example of the effectiveness of Church activity since after the above-quoted appeal the Convention was refused to be passed in the first session of Parliament shortly before the final decision of President. This homily, however, was not an isolated element of the Church's cultural policy. Another step was undertaken in form of the overnight adoration together with a prayer devoted to the rejection of this bill, supported by the Polish Episcopate with Bishop Jan Wattroba (the chairman of the Council for the Family of the Polish Episcopate) [18].

\section{The Church Policy is Based on the Sexual Matters}

Among other currently important issues is the legal status of women in Poland. The Catholic Church in Poland strives against the movements for women rights. Church clearly opposes many of the proposals on women's rights and not only stands in their way to guarantee them equal rights but also is one of the greatest obstacle to respect women's freedom and the right to choose. These matters are connected with the implicit and explicit cultural policy of Church and state authorities. Firstly, the reasons behind such state of affairs should be investigated. It is quite understandable that absence of a more unifying understanding of national culture has significantly contributed to this situation. Due to this lack of basic social and cultural foundation, various forms of cultural policies are introduced and are not "automatically" blocked by a filter called "national identity".

Church employs an ideological strategy which is based on the interpretation of the current legal changes introduced by Poland's membership in EU and claims that they are the instances of threat posed to the values of great importance to the Polish nation. The gender ideology being a case in point. This concept is presently central to Church's cultural policy. In the pastoral letter of Polish Episcopal Conference of 29 December 2013 (The Feast of the Holy Family), it was said that due to the enormous interest generated by gender ideology, a special attention should be paid to the defense of a Christian family and any kind of public information campaign should be run to raise awareness of all the threats posed to Catholic families. One of the preliminary steps of Church's cultural policy is creating a relevant definition of "genderism". Church sees gender ideology as a result of a school of thought based on Marxism and neo-Marxism, feminist movements and the sexual revolution [16].

Polish society, especially the younger generation, attempts to imitate the Western mode of life - a trend which had been much more visible after Poland's accession to the European Union in 2004. As it is a well-known fact that the human brain throughout its development is shaped by the environment, it is not surprising that various cultural forces give rise to different patterns of behavior, perception and cognition. In Poland, a large set of social and cultural patterns of behavior was shaped by a conservative model of education. And Church played a major role in its development and further transmission. As a consequence of this practice, a range of dichotomies between moral thought and ethical behavior was created which demonstrates the conflict between social norms and what is in reality cultivated by people. In Poland, there is a visible clash between general social norms and actual types of behavior preferred by society. Those strict patterns of behavior have been shaped by the Church since around $17^{\text {th }}$ century until the present day. Also, the historical background (wars with other countries, e.g. Sweden, Russia, Turkey) resulted in the situation in which social structures are created according to two models: family relations and close collegial ties of rather hermetic nature. This is why, all forms of teamwork tend to be difficult and oftentimes require the employment of some kinds of extrinsic motivation tools as a means of encouraging efficient accomplishment of the tasks.

The real impact of Church on society is mostly seen in the area of sexuality. Church persistently emphasizes the importance of marriage in one's life. In Poland, this element of cultural policy seems to be a dominant one and until now the concept of marriage have strongly permeated 
the lives of members of society and stands a symbol of a morally appropriate model of a relationship between two sexes. This pattern is a consequence of Church implicit cultural policy. On the one hand, there is society's set of rules marked by Catholic education, but on the other hand, people try to lead their lives according to natural laws and their own intuition. The reason why in Poland all acts of violence against women are not treated as criminal cases may stem from the inferior role of women in society resulted from the influence of Church cultural policy.

This dominant position of Church in Poland, in a sense, regulates male - female relationships and has an impact on how some ethical issues concerning sexuality are treated. A case in point is the EU and UN law concerning women's rights being rejected even by female representatives in Polish Parliament and it presents the attitude of Polish society towards women. This generally held view may provide us with an explanation of Church's ease of pronouncing views which are not applicable in the rapidly-changing world. Church seems to realize that a large group of female representatives will support its postulates due to the fact that female society is internally divided. It seems that two ways of referring to the social position of women co-exist in Poland. One is borrowed from the Western lifestyles, the other arises from Catholic education. It is well-known that Church has affected social attitudes to women in significant ways and that women for decades have not taken over pastoral and administrative posts in priest duties. Even though a great number of women is active in the Catholic Church, only few of them have sanctioned titles (becoming a nun does not mean being given the boon of the sacrament of Holy Orders; only men are ordained). In secular environment, a few decades had to pass for women to be regarded as full, equal partners with their husbands. This social attitude formed by Church is reflected in the way both sexes view relationships - men are more inclined to play a dominant part in a relationship and women more often feel inferior and subordinate to the partners. In this cultural and social framework, Church insists that it fights with gender ideology and that it has to take extra measures to "prevent violence and achieve equality" [16].

\section{The Church Affected the Refusal of Convention Which Combats Violence Against Women}

Despite the fact that Poland is in the process of introducing "The National Action Plan for Equal Treatment 2013-2016" and "The National Broadcasting Regulatory Strategy 2014-2016" (which aims at preventing stereotypes of women social roles in the media), the UN criticizes Poland for some forms of discrimination of women. The last report on the women's situation in Poland prepared on 7 November 2014 by the United Nations Committee on the Elimination of Discrimination against Women (CEDAW) stresses that the Polish Parliament does not fulfill its legislative obligations [9] ${ }^{1}$. These conclusions and Woleński's point of view overlap in that the Polish state authorities do not respect the aforementioned law. The Committee concludes that:

the Act on Equal Treatment of 3 December 2010 does not provide protection from sex and gender-based discrimination in areas such as education, health care, and private and family life; and that it does not adequately protect women from multiple and intersecting forms of discrimination based on ethnicity, age, disability or other grounds, in the absence of a legal definition of such forms of discrimination [9, p. 3].

The report of the UN explains briefly the situation of women in Poland:

However, it reiterates its concern about the persistence of deep-rooted gender stereotypes concerning the roles and responsibilities of women and men in the family and society, which continue to be present in the media, education materials, and are reflected by the traditional educational choices of women and their disadvantaged position in the labour market, as well as by widespread violence against women [9]. 
We tried to provide an explanation for this peculiar social status of Polish women caused by the historically dominant Church's position and which cultural policy in case of sexual issues was so effective that it contaminated secular social networks. The UN report highlights this negative role played by Church cultural policy not in the past but today: "The Committee is also concerned at the absence of measures to counter the campaign by the Polish Catholic Church against "gender ideology" and recommends that the government should "promote the equal rights of women and combat efforts made by any actors including the Catholic Church to downplay or degrade the pursuit of gender equality by labelling such measures as ideology" $[9, p$. 5]. However, it may be the case that this particular rejection of the Convention in Polish Parliament is caused not solely by Church but may be prompted by the specific kind of Polish mentality. There is yet another recommendation included in the UN report: "Encourage the media to project positive images of women and the equal status of women and men in private and public life" [9]. This statement confirms the motion that the dominant social approach reflects how society perceives both sexes only from the sexual point of view and that it may create difficulties in portraying women as someone above their corporality. Yet, this perception is fully compatible with Church's doctrine on how intercourse determines cultural and social roles. Very similar critical comments can be read in the previous UN report of 2007:

The Committee is concerned about the persistence of deep-rooted prejudice and stereotypical attitudes regarding the traditional division of roles and responsibilities of women and men in the family and in society at large [9, p. 4].

It can be seen that within those 7 years nothing has changed in Poland. From our perspective, any alternations could not be introduced due to above-mentioned peculiarities of Polish mentality. In this case, Church cultural policy has two functions. Firstly, it blocks explicitly and officially the Convention on Preventing and Combating violence against women and domestic violence. This explicit cultural policy focuses on Church attitude to state authorities and not to society, but at the same time, it has its consequences in actual social and legal status of women. Secondly, even though Church does not have any important influence on social mentality in the present-day society, the result of its power in the past can be observed today.

\section{The Polish Anticlericalism}

It should be noted that mentality of Polish society is of very peculiar nature. This social attitude towards certain ethical issues was mostly shaped by Church cultural policy in the past. This is probably why some of the new legal modifications proposed by the UN and by the EU are not received in Poland. However, in other cases, it can be observed that state authorities support Church cultural policy regardless of that fact that Church is no longer of key importance to society. This attitude of Polish society can be categorized under practical atheism.

It is not only Polish scholars (e.g. Woleński et al.) that disagree with this joint cultural policy of the state and Church but also the significant part of the society feels that something should be changed. According to the recent poll conducted by Polish Public Opinion Research Centre (CBOS) titled "Religion and the Church in public sphere" published on 13 December 2013, there is an intriguing split in the Polish society. On the one hand, Poles do accept such things as crosses hung in public places (schools and offices) (88\% answered "not offend", 10\% "oppose"), religious education in schools (82\% "not offend", 15\% "oppose"), priest participating in the public TV (74\% "not offend", 22\% "oppose). On the other hand, Poles strongly oppose direct interference of Church into secular affairs, both of private nature as those connected to politics. They disagree especially with the Church activity when it comes to acts of parliament (39\% "not offend", 55\% "oppose") and when priests try to instruct them how to vote in the elections (15\% "not offend", $82 \%$ "oppose") [21, p. 6]. It can be concluded that there has been some form of general anticlericalism among Polish society from around 16 century. 


\section{Dichotomy Between Public Policy of the Church and the Social Resonance}

There is a certain type of dichotomy in Poland when it comes to some tendencies present in the society, such as the process of naming the streets, buildings, public schools, bridges and other public structures. In Poland, at the top of the list with the names proposed for naming places in Poland is John Paul II. There is a significant number of structures of all types in public sphere that are named after Pope and other figures important from a religious point of view. The interesting fact is that the use of the names of saints seems more natural than the adaption of the names of historical figures.

This tendency may be interpreted as a way of strengthening the position of Church in public sphere [6] by the government, however, irrespective of the general preference of the society. One of the recent online referenda held to vote on the new names for six traffic circles in one of the districts in Warsaw illustrates this tendency. For all six roundabouts, secular names were chosen (including the name of a Polish heart surgeon and an atheist Zbigniew Religa) [24] and none of the religious names was favored. Nevertheless, state authorities when deciding on the names invariably opt for religious ones.

It is worth remembering that the Enlightenment, which stretched from around 1650s to about 1780s, significantly altered ideas concerning religion, reason, nature and man. This intellectual movement put stronger emphasis on reason, analysis and individualism and fuelled heated debates and criticism of religion and provided ground for the development of novel religious ideas, such as Deism and atheism. Much of the revolutionary ideas in Europe were provided by scholars and philosophers. However, this was not the case in Poland where the main figures of this movement were priests (e.g. Hugo Kołłątaj, Franciszek Bohomolec, Bishop Ignacy Krasicki). Maybe the fact that this movement in Poland was so strongly marked with religious influence and not with the scholar trains of thought was one of the reasons why the Polish Church cultural policy is nowadays of chief importance, at least for state authorities. This, in turn, results in a lack of debates on secularization and privatization of religion which are held in other Western countries. This may also be a binder that connects cultural policy of the state with Church policy so strongly that it is not so openly criticized and questioned by the society.

\section{Conclusion}

Two forms of dichotomy can be observed in Poland. The first one is visible in the division between state and Church cultural policies and the religiously indifferent Polish society. The cultural policy in Poland is, in most cases, guided by the demands of Church and effectively enforced by state authorities despite the fact that it is not consistent with the Polish constitution (e.g. religious education) or Council of Europe Convention on preventing and combating violence against women and domestic violence, rejected by Church and until recently by state authorities. Another instance of dichotomy can be seen in the sphere of social attitudes towards the teaching of Church. This attitude can be categorized as practical atheism or indifferentism connected with anticlericalism. It may be the case that the opposition to clerks causes indifferentism or it might be the other way round - anticlericalism stems from indifferentism of the society which demonstrates in this way its desire of self-direction in the moral issues.

The Church in Poland attempts to wield influence on society through both implicit and explicit policy executed by state authorities to regulate matters such as sexuality. From a historical point of view, it is one of the oldest and most basic tools of Church cultural policy [12, p. 475] which in a present-day Poland is in opposition to practical atheism and indifferentism of Polish society.

Cognitive science of religion's researchers identified a distinction between intuitive and reflective beliefs; they also proposed a hypothesis concerning theological incorrectness (difference between official religious beliefs and the interpretations of it by believers) [4]. Still, regardless of 
this natural human tendency and secularizing process, church make use of his obsolete strategy to strengthen its presence in secular culture. In Poland, this process is of distinct nature when compared to "global" Church as it was described by Bennett [6]. The "global" Church strategy is based on implicit policy implemented by means of the media (e.g. strategic canonization or public life of Pope Francis), whereas Polish Church combines two strategies of cultural policy: implicit cooperation with successive state authorities (after 1989, regardless of their official political affiliations) and explicit impact on moral life of believers. In some cases, it is difficult to distinguish Church attempts to achieve its goals through the government from the strategy of politicians who seem only to take into consideration Church's demands as to, for instance, win the elections (even if the polls demonstrate that Poles do not wish priests to tell them how to vote).

The Church has specific moral background which is deeply rooted in the idea of the existence of another parallel reality. Christian background evokes ideas and behavioral patterns associated with the patterns of poverty and service. Above-mentioned historical context in Poland has connected the Church with the low level of identity of society with the state. However, this rather historical than moral and ideological correlation is insufficient in the current polish society which from 1989 is opened for all secular ideas and processes. These processes which have been working much earlier in the Western countries have affected institutional secularization and the great change of the Church attitude towards society and the state. It seems that good example of appropriate church policy in secularized societies is, on the lower level, public policy of John Paul II. This pope has tried to find balance between orthodox and secularization and he has excluded sometimes from his public teaching some normative, doctrinal claims which could block unity and social peace [23]. We can find a difference between the Church in Poland and the Church in the western countries which seem to be more affected by this ideologically neutral public teaching of John Paul II. When we look from a historical point of view we can find that the best solution for religious institutions in the time of secularization is to avoid strong political engagement and to focus on moral activity which is in line with democratic rules of the ideologically plural society.

\section{References}

1. Apel o ratyfikacje Konwencji o zwalczaniu $i$ zapobieganiu przemocy wobec kobiet $i$ przemocy domowej [Appeal for Ratification of Convention on preventing and combating violence against women and domestic violence] [online]. Available from: https://www.change.org/p/rafa\%C5\%82-grupi\%C5\%84ski-apel-o-ratyfikacj\%C4\%99-

konwencji-o-zwalczaniu-i-zapobieganiu-przemocy-wobec-kobiet-i-przemocy-domowej [accessed 16 November 2014].

2. Baniak, J. Religia katolicka i Kościót rzymskokatolicki $w$ opiniach polskiej młodzieży: od akceptacji do kontestacji [The catholic religion and the catholic Church in the opinions of the polish youth: from an acceptance to contestation]. Kraków: Zakład wydawniczy Nomos, 2015.

3. Baniak, J. Portret księdza $w$ wyobrażeniach $i$ ocenach polskiej młodzieży: studium socjologiczne [The image of priest in imaginations and opinions of the polish youth: a sociological study]. Kraków: Zakład wydawniczy Nomos, 2015.

4. Barrett, J. L. The Naturalness of religious Concepts. An emerging Cognitive Science of Religion, in Antes, P., Geertz, A. W., Warne, R. W., New Approaches to the Study of Religion, vol. 2. Berlin: Walter de Gruyter, 2004.

5. Bennett, O. On religion and cultural policy: notes on the Roman Catholic Church, International Journal of Cultural Policy, Vol. 15, No. 2, May, 2009.

6. Bennett, O. Strategic canonisation: sanctity, popular culture and the Catholic Church, International Journal of Cultural Policy, Vol. 17, No. 4, September, 2011.

7. Casanova, J. Public Religions in the Modern World. The University of Chicago Press, 1994.

8. Committee on the Elimination of Discrimination against Women. 2007. Concluding comments of the Committee on the Elimination of Discrimination against Women: Poland, 2 
February

[online].

Available

from:

http://www.refworld.org/publisher,CEDAW,CONCOBSERVATIONS,POL,45f6d0a66,0.ht $\mathrm{ml}$ [accessed 29 November 2014].

9. Committee on the Elimination of Discrimination against Women. 2014. Concluding observations on the combined seventh and eighth periodic reports of Poland, 7 November 2014 [online].

Available

from: http://tbinternet.ohchr.org/_layouts/treatybodyexternal/Download.aspx?symbolno=CEDAW $\% 2 \mathrm{fC} \% 2 \mathrm{fPOL} \% 2 \mathrm{fCO} \% 2 \mathrm{f} 7-8 \& \mathrm{Lang}=\mathrm{en}$ [accessed 29 November 2014].

10. Council of Europe Convention on preventing and combating violence against women and domestic violence [online]. Available from: http://conventions.coe.int/Treaty/EN/Treaties/html/210.htm [accessed 16 November 2014].

11. Dziwisz, S. Kraków miastem wyuzdania - pisze $w$ liście do wiernych kard. Stanisław Dziwisz [Cracow the City of Licentiousness - Cardinal Stanislaw Dziwisz writes in the Letter to the Believers] [online]. Available from: http://www.radiokrakow.pl/wiadomosci/krakow/krakow-miastem-wyuzdania-pisze-w-lisciedo-wiernych-kard-stanislaw-dziwisz/ [accessed 16 November 2014].

12. Gaydos, L. M., Smith, A., Hogue, C. J. R., Blevin, J. An Emerging Field in Religion and Reproductive Health, Journal of Religion and Health, Vol. 49, No. 4, December 2010.

13. Graff, A. Report from the gender trenches: War against 'genderism' in Poland, European Journal of Women's Studies, November 21, 2014.

14. Konwencja antyprzemocowa znowu zablokowana. 'Tak Platforma pomaga PiS-owi' [Anti Violence Convention blocked again] [online]. Available from: http://m.wiadomosci.gazeta.pl/wiadomosci/1,117915,16842331,Konwencja_antyprzemoco wa_znowu_zablokowana_Tak_Platforma.html [accessed 16 November 2014].

15. Lipien, T. Wojtyła a kobiety. Jak zmienia się Kościót [Wojtyła and the Women. How the Church changes], transl. J. Kabat, Warszawa, 2010.

16. List pasterski na Niedzielę Świętej Rodziny 2013 roku. [Pastoral letter of the Bishops' Conference of Poland to be used on the Sunday of the Holy Family 2013] [online]. Available

from: http://episkopat.pl/dokumenty/5545.1,List_pasterski_na_Niedziele_Swietej_Rodziny_2013_ roku.html [accessed 11 November 2014].

17. Mcguigan, J. Rethinking cultural Policy. Open university Press, 2004.

18. Modlitewna ofensywa za życiem [Prayer Offensive for Life] [online]. Available from: http://naszdziennik.pl/wiara-kosciol-w-polsce/98383,modlitewna-ofensywa-za-zyciem.html [accessed 16 November 2014].

19. Norris P., Inglehart R. Sacred and Secular. Religion and Politics Worldwide. Cambridge university Press, 2012.

20. Radkowska-Walkowicz, M. Frozen children and despairing embryos in the 'new' postcommunist state: The debate on IVF in the context of Poland's transition, European Journal of Women's Studies, November 21, 2014, pp. 399-414.

21. Religia i Kościót w przestrzeni publicznej [Religion and the Church in the public sphere], CBOS [online]. Available from: http://www.cbos.pl/SPISKOM.POL/2013/K_170_13.PDF [accessed 16 November 2014].

22. Ryczan, K. Bp Ryczan na Jasnej Górze: „Europa nie ma prawa dotykać laickimi rękami naszej rodziny!” [Bishop Ryczan in Jasna Gora: „Europe can not touch his secular Hands our Family!'] [online]. Available from: http://www.diecezja.kielce.pl/bp-ryczan-na-jasnejgorze-europa-nie-ma-prawa-dotykac-laickimi-rekami-naszej-rodziny [accessed November 2014].

23. Szocik, K., Jana Pawła II idee filozoficzne. Między ortodoksja a sekularyzacja [Philosophical ideas of John Paul II. Between orthodox and secularization], Warszawa: Wydawnictwa Uniwersytetu Warszawskiego 2015. 
24. Szocik, K. Roots of self-domestication, Science, 28 November, Vol 346, Issue 6213, 2014, p. 1067.

25. Konkurs na wytonienie nazw dla 6 bezimiennych rond na Ursynowie rozstrzygnięty! [online]. Available from: http://ursynow.pl/2014/11/konkurs-na-wylonienie-nazw-dla-6bezimiennych-rond-na-ursynowie-rozstrzygniety/ [accessed 29 November 2014].

26. Woleński, J. Discussion, in. Leszczyński, D. (ed.), Wiara, wiedza, uzasadnienie [Faith, Knowledge, Justification]. Wrocław: Atla 2, 2008.

27. Woleński, J. Apel do władz Rzeczypospolitej Polskiej w sprawie klerykalizacji kraju [Appeal to the Authorities of the Republic of Poland in case of Clericalization of the Country] [online]. $\quad$ Available from: http://wyborcza.pl/1,75968,16817936,Apel_do_wladz_Rzeczypospolitej_Polskiej_w_spraw ie.html [accessed 16 November 2014].

28. Woleński, J. Kolejne postulaty Kościoła psuja nasze państwo [Next the Church demands damage our state] [online]. Available from: http://m.wyborcza.pl/wyborcza/1,105402,16848629.html?i=0 [accessed 16 November 2014].

\section{Notices}

${ }^{1}$ The Polish Parliament has been accepted „Convention on preventing and combating violence against women and domestic violence" on $6^{\text {th }}$ February 2015. Despite this delayed acceptance of this document, we can observe specific political and cultural game between three actors in Poland: the state authority, the Church and society. Now, the leading concepts in this game or, better, in this battle, are "gender" and "women". 